\title{
Regulation of the Type III Secretion System in Phytopathogenic Bacteria
}

\author{
Xiaoyan Tang, ${ }^{1}$ Yanmei Xiao, ${ }^{1}$ and Jian-Min Zhou ${ }^{2}$ \\ ${ }^{1}$ Department of Plant Pathology, Kansas State University, Manhattan, KS 66506-5502, U.S.A.; ${ }^{2}$ National Institute \\ of Biological Sciences, Beijing, China
}

Submitted 18 April 2006. Accepted 10 June 2006.

\begin{abstract}
The type III secretion system (TTSS) is a specialized protein secretion machinery used by numerous gram-negative bacterial pathogens of animals and plants to deliver effector proteins directly into the host cells. In plant-pathogenic bacteria, genes encoding the TTSS were discovered as hypersensitive response and pathogenicity (hrp) genes, because mutation of these genes typically disrupts the bacterial ability to cause diseases on host plants and to elicit hypersensitive response on nonhost plants. The hrp genes and the type III effector genes (collectively called TTSS genes hereafter) are repressed in nutrient-rich media but induced when bacteria are infiltrated into plants or incubated in nutrient-deficient inducing media. Multiple regulatory components have been identified in the plant-pathogenic bacteria regulating TTSS genes under various conditions. In Ralstonia solanacearum, several signal transduction components essential for the induction of TTSS genes in plants are dispensable for the induction in inducing medium. In addition to the inducing signals, recent studies indicated the presence of negative signals in the plant regulating the Pseudomonas syringae TTSS genes. Thus, the levels of TTSS gene expression in plants likely are determined by the interactions of multiple signal transduction pathways. Studies of the hrp regulons indicated that TTSS genes are coordinately regulated with a number of non-TTSS genes.
\end{abstract}

Numerous gram-negative bacterial pathogens of plants and animals rely on the type III secretion system (TTSS) to invade their hosts (Galan and Collmer 1999). The TTSS is a syringe needle-like structure consisting of inner and outer membrane rings and a protruding filament called hrp pilus in the plant pathogens (Kubori et al. 1998; Marlovits et al. 2004; Roine et al. 1997; Van Gijsegem et al. 2000; Weber et al. 2005). The hrp pilus functions as a conduit to guide the translocation of the type III effectors to the interior of the host cells (Jin and $\mathrm{He}$ 2001; Li et al. 2002). The TTSS is encoded by a cluster of approximately 20 hypersensitive response and pathogenicity ( hrp) genes that are organized into several operons on either the chromosome or plasmid of plant-pathogenic bacteria (Arnold et al. 2003). The hrp gene clusters often are flanked by several type III effectors and other types of virulencerelated genes; together, these genes form the pathogenicity island that is defined from the rest of the genome by tRNA or mobile elements (Alfano et al. 2000; Arnold et al. 2003). Addi-

Corresponding author: Xiaoyan Tang; Telephone: 785-532-1345; Fax: 785-532-5692; E-mail: xtang@ksu.edu tional type III effector genes are scattered in the rest of the bacterial genomes either in clusters or singly (Arnold et al. 2003). The expression of TTSS genes is coordinately regulated by various host and environmental factors (Arlat et al. 1992; Rahme et al. 1992; Schulte and Bonas 1992; Wei et al. 1992; Xiao et al. 1992). According to the hrp operon structures and the regulatory systems controlling TTSS gene expression, the hrp genes of the plant bacterial pathogens are divided into two main groups. The hrp genes of Erwinia spp., Pantoea stewartii, and Pseudomonas syringae belong to group I, and those of Xanthomonas spp. and Ralstonia solanacearum are in group II (Alfano and Collmer 1997). Multiple signal transduction components have been identified for both groups of the hrp genes (Fig. 1A and B). This review will highlight hrp gene regulation in these phytopathogenic bacteria.

The regulatory system for group I hrp genes.

Group I hrp genes in Erwinia spp., Pantoea stewartii, and $P$. syringae are regulated by $\mathrm{HrpL}$, a member of the ECF family of alternative sigma factors (Frederick et al. 2001; Wei and Beer 1995; Xiao et al. 1994). The HrpL proteins of these bacteria are highly conserved in amino acid sequences and all recognize a consensus sequence (GGAACC-N15/16-CCACNNA) named the "hrp box" in the promoters of the hrp operons and type III effectors (Fouts et al. 2002; Frederick et al. 2001; Wei and Beer 1995). The hrp box motif contains two conserved modules. Recent studies in Pantoea agglomerans pv. gypsophilae indicated that the hrp box consensus can be divided into crucial and noncrucial nucleotides. The five nucleotides (GGAAC) in the upstream module and the three nucleotides (ACNNA) in the downstream module are crucial, whereas other consensus and adjacent nonconsensus nucleotides exert a significant effect on the promoter's strength (Nissan et al. 2005). The hrp box consensus sequence has served as an important genomic marker for the identification of candidate type III effector genes of the group I bacteria via computational analysis (Fouts et al. 2002; Zwiesler-Vollick et al. 2002). In addition, several functional genomic approaches have been developed to identify the type III effector genes in Pseudomonas syringae strains based on their dependence on $h r p L$ for induction (Chang et al. 2005; Fouts et al. 2002; Lan et al. 2006; Losada et al. 2004). It was shown recently that HrpL directly binds the hrp box motif in gel shift assay but, surprisingly, mutations of the consensus nucleotides in the downstream module that eliminate the promoter activity do not affect the HrpL-binding (Nissan et al. 2005).

Consistent with the role as the transcriptional activator of TTSS genes, $h r p L$ itself also is induced under the $h r p$-inducing 
conditions (Chatterjee et al. 2002; Merighi et al. 2003; Xiao et al. 1994). The hrpL induction requires $h r p S$ in Erwinia spp. and Pantoea stewartii and hrpS and hrpR in P. syringae (Hutcheson et al. 2001; Merighi et al. 2003; Nizan-Koren et al. 2003; Wei et al. 2000b). The HrpS proteins in Erwinia spp., Pantoea stewartii, and P. syringae share significant amino acid identify. The $h r p R$ gene is present in $P$. syringae but not in Erwinia spp. and Pantoea stewartii. The hrpR and hrpS genes are organized in an operon controlled by the promoter upstream of $h r p R$ (Grimm et al. 1995; Hutcheson et al. 2001; Xiao et al. 1994). The HrpR and HrpS proteins belong to the NtrC family of two-component regulator proteins but lack the $\mathrm{N}$-terminal receiver domain, suggesting that the transcription regulator activity of $\mathrm{HrpR}$ and $\mathrm{HrpS}$ is not regulated directly by phosphorylation (Xiao et al. 1994). The two proteins are highly homologous in sequence and form a heterodimer. The dimerization is believed to be crucial for the transcriptional activation of $h r p L$ (Hutcheson et al. 2001). $h r p S$ alone is capable of activating the $h r p L$ gene in $P$. syringae but only at a very low level, and the maximal induction of $h r p L$ requires both hrpR and hrpS (Bretz et al. 2002; Grimm et al. 1995; Hutcheson et al. 2001). Both HrpR and HrpS contain an enhancer-binding domain and a motif that interacts with the $\sigma^{54}$ RNA polymerase holoenzyme. Consistently, transcription of $h r p L$ is under the control of a $\sigma^{54}$-dependent promoter in an alternate $\sigma$ factor RpoN-dependent manner (Chatterjee et al. 2002; Hendrickson et al. 2000). It was hypothesized that, under inducing conditions, HrpR and HrpS form a heterodimer on the $h r p L$ promoter to stimulate the transcription of $h r p L$ by interacting with the RpoN-RNA polymerase holoenzyme (Hutcheson et al. 2001). Additional regulators of $h r p L$ were reported in Erwinia carotovora subsp. carotovora that include the RsmA/rsmB RNA-mediated post-transcriptional system and genes affecting the RsmA/rsmB production (Chatterjee et
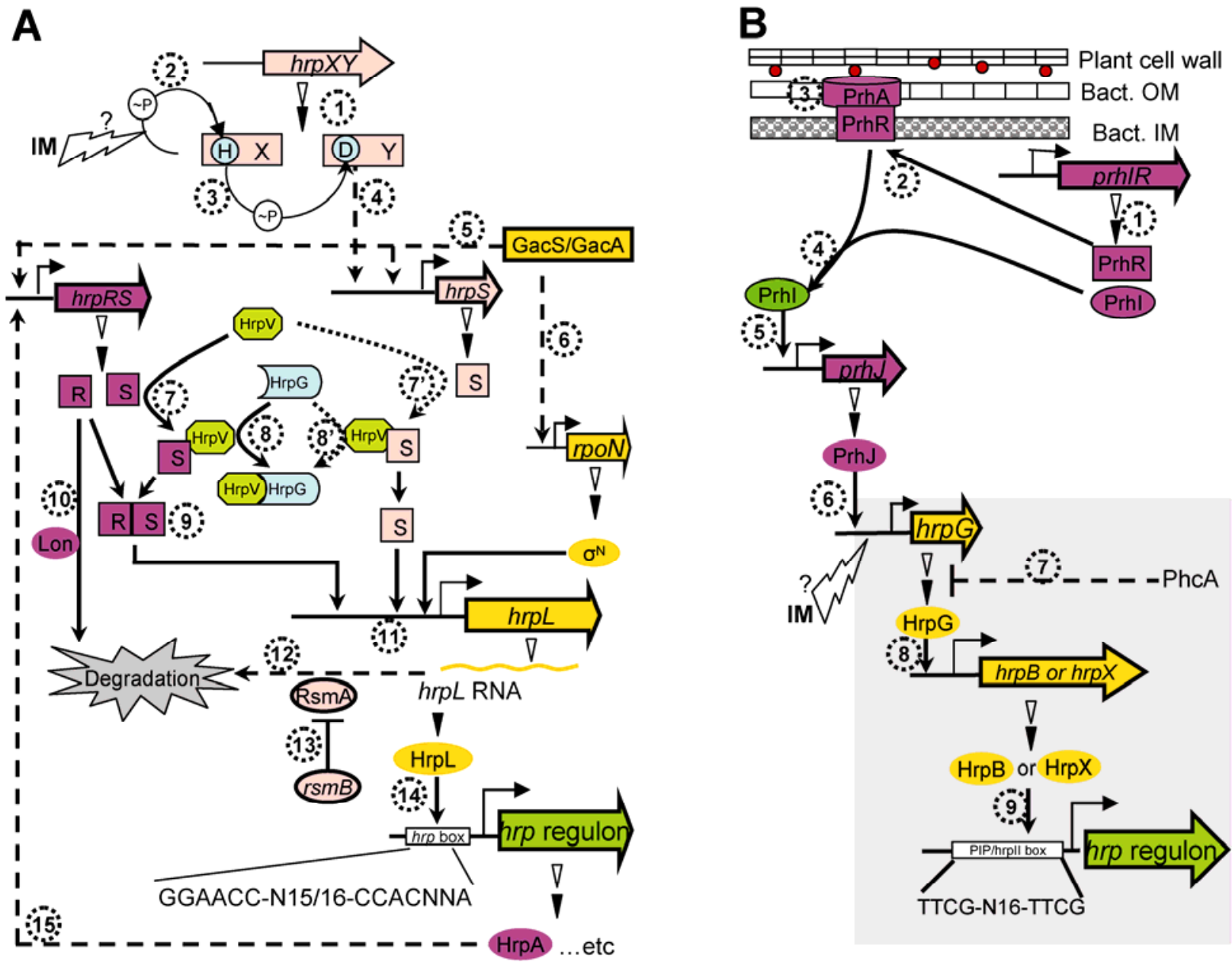

Fig. 1. Models of type III secretion system (TTSS) gene regulation in phytopathogenic bacteria. The numbers indicate the major signaling events. A, Group I bacteria. 1, The hrpXY operon in Erwinia spp. and Pantoea stewartii is transcribed and translated into HrpX and HrpY proteins. 2, Signal in inducing medium (IM) triggers autophosphorylation of HrpX. 3, HrpX phosphorylates HrpY. 4, HrpY activates the transcription of hrpS through an unknown mechanism. 5, GacS/GacA activates the transcription of hrpS in Erwinia spp. and Pantoea stewartii and hrpRS in Pseudomonas syringae. 6, GacS/GacA activates the transcription of rpoN in Erwinia spp., Pantoea stewartii, and P. syringae. 7 and 7', HrpS is repressed by HrpV via protein-protein interaction. 8 and 8', HrpG interacts with $\mathrm{HrpV}$ and derepresses HrpS. 9, HrpS and HrpR proteins form heterodimer in P. syringae. 10, HrpR protein is degraded by Lon protease in $P$. syringae. 11, HrpR and HrpS in P. syringae and HrpS in Erwinia spp. and Pantoea stewartii associate with RpoN in the hrpL promoter to activate hrpL expression. 12, hrpL RNA is degraded by RsmA-dependent mechanism. 13, rsmB RNA inhibits the function of RsmA. 14, HrpL recognizes the hrp box promoter and activates the transcription of hrp regulons. 15, HrpA acts upstream of hrpRS transcription to stimulate TTSS gene expression. B, Group II bacteria. 1, PrhI and PrhR proteins are encoded by the prhIR operon. 2, PrhR protein is located in the bacterial inner membrane. 3, PrhA protein located in the outer membrane perceives the plant cell wall signal and transfers the signal to PrhR. 4, PrhR activates PrhI. 5, PrhI activates the transcription of prhJ. 6, PrhJ activates the transcription $h r p G$. 7, PhcA represses $h r p G$ at the post-transcriptional level. 8, HrpG activates the transcription of hrpX in Xanthomonas spp. and hrpB in Ralstonia solanacearum. 9, HrpX and HrpB activate the PIP/hrpII box promoters. Components of group II bacteria in the shaded area are required for $h r p$ gene activation in both inducing medium and plants. Components in the unshaded area are $R$. solanacearum genes specifically required for $h r p$ gene activation in plants. IM indicates unknown signal in inducing medium. 
al. 2002). RsmA is a small RNA-binding protein that promotes RNA decay (Chatterjee et al. 1995). The $r s m B$ RNA, on the other hand, acts as positive regulator, presumably by sequestering RsmA (Liu et al. 1998). The hrpL RNA level is barely detectable in the mutant strain of $\operatorname{rsmB}$ but accumulates to a high level in a mutant lacking RsmA (Chatterjee et al. 2002).

A two-component system consisting of hrpX and $h r p Y$ acts upstream of the hrpS-hrpL cascade in Erwinia spp. and Pantoea stewartii (Merighi et al. 2003; Nizan-Koren et al. 2003; Wei et al. 2000b). hrpX encodes the sensor histidine kinase, whereas $h r p Y$ encodes the corresponding response regulator. The $h r p X$ and $h r p Y$ genes constitute an operon between the $h r p L$ and $h r p S$ loci in the hrp gene cluster (Merighi et al. 2003; Mor et al. 2001; Nizan-Koren et al. 2003; Wei et al. 2000b). Mutagenesis analysis indicated that phosphorylation of HrpY, likely by HrpX, is crucial to its function in activating the hrpShrpL-hrp cascade (Nizan-Koren et al. 2003). hrpXY is required for the hrp gene induction in inducing medium. Perhaps HrpX perceives chemical or physiological signals in the inducing medium, which in turn activates HrpY by phosphorylation. How HrpY activates the hrpS gene remains to be elucidated. The hrp gene cluster of $P$. syringae does not harbor a $h r p X Y$ like locus. However, the $P$. syringae genomes contain a large number of two-component system gene loci (Buell et al. 2003; Feil et al. 2005; Joardar et al. 2005); it is unknown if any of these loci encodes the functional cognates of HrpX/HrpY.

Multiple components have been found to regulate the $h r p R$ and hrpS genes in P. syringae at different levels. The hrpRS transcription displayed two- to fourfold induction in both inducing medium and plants, and this induction precedes the induction of $h r p L$ and other TTSS genes. This induction was detected in several $P$. syringae pv. phaseolicola strains as well as the P. syringae pv. tomato DC3000 strain (Rahme et al. 1992; Thwaites et al. 2004) (L. Lan and X. Tang, unpublished results). The GacS/GacA two-component system was found to play a role in regulating the hrpRS expression in $P$. syringae (Chatterjee et al. 2003). GacS is the sensory histidine kinase, whereas GacA is the cognate response regulator. The GacS/GacA system is found in numerous bacteria, and this system serves as a master regulator of many bacterial phenotypes, including pathogenicity, production of toxin and antibiotics, quorum sensing, motility, production of exopolysaccharides, biofilm formation, and stress tolerance (Heeb and Haas 2001). In $P$. syringae pv. tomato DC3000, the gacA mutation attenuates significantly the transcription of $h r p R S, r p o N$, and $h r p L$ (Chatterjee et al. 2003). Because $h r p L$ is regulated by $h r p R S$ and $r p o N$, the reduced $h r p L$ expression in the gacA mutant likely results from the reduced expression of hrpRS and rpoN. The signal perceived by GacS and the mechanism by which GacA regulates the expression of hrpRS and rpoN are unknown. In addition to the GacA/GacS system, HrpA, the major component of the type III pilus, also was found to affect the transcription of the hrpRS operon (Wei et al. 2000a). In an hrpA mutant, transcription of the $h r p R S$ operon, $h r p L$, and other TTSS genes is severely reduced, and this can be restored by $h r p R S$ overexpression. The mechanism by which HrpA regulates the $h r p R S$ locus is unclear.

The ATP-dependent Lon protease is a negative regulator of the HrpR protein (Bretz et al. 2002). Lon was identified as a negative regulator of the $P$. syringae TTSS genes, of which the mutant displayed constitutive hrp gene activation in the rich medium (Bretz et al. 2002) (Y. Xiao and X. Tang, unpublished results). Mutation of $l o n$ in $P$. syringae increased the protein stability of HrpR but not HrpS in both the rich medium and the inducing medium (Bretz et al. 2002). In the wild-type P. syringae strain, the HrpR protein displayed greater instability in the rich medium than in the inducing medium. This is consistent with the reduced level of the Lon protein in the inducing medium (X. Deng and X. Tang, unpublished result). The constitutive activation of TTSS genes in the lon mutant in the rich medium likely results from the HrpR protein accumulation. The lon mutation does not significantly affect the transcription of the hrpRS locus in the rich medium (L. Lan and X. Tang, unpublished result). Thus, it is likely that the wild-type $P$. syringae strain and the lon mutant have similar levels of HrpS protein, because the Lon protease does not modulate the HrpS protein stability. However, the lon mutant displays higher expression of TTSS genes in the repressive medium than does the wild-type strain. This observation further supports the role of $\mathrm{HrpR}$ as coactivator of $\mathrm{HrpS}$ in inducing the $h r p L$ gene. In addition to its role in regulating the HrpR protein, Lon protease was reported to regulate the stability of type III effectors in P. syringae (Losada and Hutcheson 2005).

It was reported recently that the HrpS function is regulated by $\mathrm{HrpV}$ and HrpG by a mechanism similar to the anti-anti-activator mechanism in $P$. aeruginosa (Wei et al. 2005). In $P$. aeruginosa, expression of TTSS genes is controlled at the transcriptional level by ExsA, an AraC-like transcriptional activator (Hovey and Frank 1995). The anti-activator ExsD interacts with ExsA in repressive conditions and, thus, represses the transcription of TTSS genes (McCaw et al. 2002). When the bacteria are grown in the inducing conditions, a third regulator, ExsC, interacts with ExsD and releases ExsA from inhibition by ExsD that, in turn, activates TTSS gene expression (Dasgupta et al. 2004). In this model, ExsD acts as an anti-activator of ExsA, and ExsC acts as an anti-anti-activator. In $P$. syringae, $h r p G$ and $h r p V$ genes are located in the $h r c C$ operon and are specific to the group I $h r p / h r c$ gene cluster. HrpV is a negative regulator of TTSS genes upstream of HrpR/HrpS (Preston et al. 1998). In inducing medium, $h r p$ genes are expressed at an elevated level in $h r p V$ mutants, whereas overexpression of the $h r p V$ gene abolishes TTSS gene expression. HrpG, a chaperone-like protein, can derepress TTSS gene expression in an $h r p V$-overexpression strain without affecting the $h r p V$ transcription (Wei et al. 2005). It has been demonstrated further that HrpV interacts with HrpS and HrpG in vivo (Wei et al. 2005). Thus, it is likely that HrpG suppresses HrpV via a protein-protein interaction to free $\mathrm{HrpS}$ in the inducing conditions. In this hypothesis, HrpV acts as anti-activator of HrpS, and $\mathrm{HrpG}$ is an anti-anti-activator.

\section{The regulatory system for group II hrp genes.}

Most group II $h r p$ operons are activated by an AraC-like activator, which was designated $\mathrm{HrpB}$ in $R$. solanacearum (Genin et al. 1992) and HrpX in Xanthomonas spp. (Kamdar et al. 1993; Wengelnik and Bonas 1996). The HrpX and HrpB proteins are highly similar at the amino acid level. The promoters of $h r p$ operons and type III effector genes regulated by HrpX and HrpB often carry a conserved motif termed plantinducible promoter (PIP)-box (TTCGC-N15-TTCGC) in Xanthomonas spp. (Buttner and Bonas 2002) and hrpII-box (TTCG-N16-TTCG) in $R$. solanacearum (Cunnac et al. 2004a). Individual mutations of the PIP/hrpII-box consensus nucleotides generally reduce the promoter activity; however, alterations of the space between the two conserved modules abolish the promoter induction (Cunnac et al. 2004a; Tsuge et al. 2005). A search of the Xanthomonas spp. and R. solanacearum genome sequence with this consensus sequence identified a large number of candidate type III effector genes (Cunnac et al. 2004b; da Silva et al. 2002; Thieme et al. 2005). Some of these genes were identified as the $h r p X / h r p B$-induced genes by microarray, promoter trap assay, and cDNA differential display (Mukaihara et al. 2004; Noel et al. 2001; Occhialini et al. 2005). Nonetheless, it should be pointed out that several well- 
characterized type III effector genes in Xanthomonas spp., including avrBs 1 and members of the avrBs 3 family, are constitutively expressed and do not have a PIP-box in their promoters. Even the promoters of some HrpX/HrpB-regulated effector genes do not have the PIP/hrpII-box and, thus, probably are regulated indirectly by $\mathrm{HrpX} / \mathrm{HrpB}$ (Buttner and Bonus 2002; Occhialini et al. 2005).

The $h r p X$ and $h r p B$ genes are activated by the HrpG proteins in Xanthomonas spp. and R. solanacearum (Brito et al. 1999; Wengenilk et al. 1996). The HrpG proteins in Xanthomonas spp. and $R$. solanacearum share $>40 \%$ amino acid identity. HrpG belongs to the OmpR family of the two-component response regulators, with an $\mathrm{N}$-terminal receiver domain and a C-terminal DNA-binding motif (Brito et al. 1999; Wengenilk et al. 1996). Using the yeast two-hybrid analysis, HrpG of Xanthomonas axonopodis pv. citri was found to interact with a two-component system sensor kinase and a few other bacterial proteins of unknown function (Alegria et al. 2004); it remains to be determined whether this sensor kinase has the ability to phosphorylate HrpG of its receiver domain and whether phosphorylation of $\mathrm{HrpG}$ is important to its regulatory activity. Nonetheless, three point mutations in the HrpG protein of $X$. campestris pv. vesicatoria render the protein constitutively active even under TTSS repressive conditions (Wengenilk et al. 1999), suggesting that conformational change of the HrpG protein likely plays an important role in TTSS gene regulation.

HrpG in $R$. solanacearum is a converging point of signal transduction pathways mediating TTSS gene induction (Brito et al. 2002). hrpG is constitutively expressed in complete and minimal media but induced by a plant-specific signal (Brito et al. 1999). Four signal transduction components acting upstream of $h r p G$ to mediate the $h r p$ gene induction specifically in plants are discussed in the following section. It has been identified recently that $\mathrm{PhcA}$ is a negative regulator of the $\mathrm{HrpG}$ protein in complete medium, probably via a post-transcriptional mechanism (Genin et al. 2005). PhcA is a LysR family transcriptional regulator that coordinates the expression of multiple virulence factors such as exopolysaccharides, various plant cell-wall-degrading enzymes, quorum sensing, and bacterial motility (Schell 2000). The phcA mutation does not affect the transcription of $h r p G$ but elevates the expression of TTSS genes in the complete medium (Genin et al. 2005).

\section{Regulation of TTSS genes \\ by host and environmental signals.}

Host sensing is critical for a successful infection by bacterial pathogens. Upon sensing the host, pathogenic bacteria reprogram their transcription, which results in coordinated activation of TTSS genes (Brencic and Winans 2005). Animal bacterial TTSS genes are activated upon contact with host cells (Francis et al. 2002). In Yersinia pseudotuberculosis, the contact with Hela cells is believed to trigger the release of LcrQ, a type III secreted protein that negatively regulates TTSS gene expression (Pettersson et al. 1996). This TTSS-dependent feedback regulation also operates the contact-induction of TTSS genes in Y. enterocolitica (Stainier et al. 1997).

Several studies elegantly demonstrated that the $R$. solanacearum TTSS genes are induced when the bacterium is in contact with the plant cell (Aldon et al. 2000). Unlike animal bacteria, the contact-dependent induction of type III genes in Ralstonina spp. does not require the type III pilus. Instead, it is mediated by PrhA, a membrane protein with significant similarities with siderophore receptors (Marenda et al. 1998). The prhA mutation disrupts the contact-dependent type III gene induction but not the induction by the minimal medium (Marenda et al. 1998), suggesting that distinct signals are perceived from host cell and culture medium. The plant signal perceived by
PrhA is likely a nondiffusible plant wall component that is resistant to protease and heat treatments (Aldon et al. 2000); however, the chemical nature of the signal remains unknown. Additional components acting downstream of PrhA are PrhR, PrhI, PrhJ, HrpG, and HrpB that function in a sequential order (Brito et al. 1999, 2002). HrpG and HrpB are required for induction of TTSS genes in both minimum medium and plants, whereas PrhR, PrhI, and PrhJ are required specifically for the induction by plant cells. prhR and prhI are in the same operon and encode a transmembrane protein and a sigma factor of the ECF family, respectively (Brito et al. 2002). PrhJ is a LuxR/UhpA family transcription activator (Brito et al. 1999). PrhR and PrhI act upstream of PrhJ and, together, the three proteins are required for the induction of $h r p G$ which, in turn, activates $h r p B$ in response to host cell contact. According to Brito and associates (2002), a plant cell-wall-derived signal, likely a macromolecule, is perceived by PrhA. PrhA subsequently transfers the signal to PrhR, which sequentially activates the transcription factor genes $p r h I, p r h J, h r p G$, and $h r p B$. The prhA, prhJ, prhI, and prhR mutants all are affected in pathogenicity in Arabidopsis and hypersensitive response (HR) in resistant plants (Brito et al. 1999, 2002; Marenda et al. 1998). In particular, the prhJ mutant is completely nonpathogenic in plants. Together, the results demonstrate that host-cell sensing by $R$. solanacearum is fundamental to pathogenesis.

The involvement of plant-specific signals in inducing TTSS genes is likely true for other bacteria as well. For example, it was reported that induction of the $P$. syringae pv. phaseolicola hrpL gene in planta is much greater compared with the induction by the inducing medium, suggesting the presence of a plant-derived signal (Rahme et al., 1992). In addition, mutants of a conserved hypothetical protein have been isolated recently in two pathovars of $P$. syringae that completely abolish the hrp promoter induction in plant but only marginally affect the hrp promoter induction in the inducing medium. The mutants displayed significantly reduced pathogenicity on their host plants, bean and tomato, and the HR-inducing activity on the nonhost tobacco plants (Y. Xiao and X. Tang, unpublished results). Similarly, a heat-stable compound derived from a plant suspension culture was reported to induce TTSS genes of $X$. campestris pv. vesicatoria (Schulte and Bonas 1992).

Certain environmental conditions, including temperature, medium composition, and $\mathrm{pH}$, also affect TTSS gene expression (Arlat et al. 1992; Huynh et al. 1989; Rahme et al. 1992; van Dijk et al. 1999; Wei et al. 1992). TTSS genes of plant bacteria are suppressed by rich media but induced by minimal synthetic media. The inhibitory activity of rich media is exerted by high $\mathrm{pH}$ and osmolarity and complex carbon and nitrogen nutrient sources. TTSS-inducing media are acidic, low osmotic, nutritionally poor, and contain certain sugars as the carbon source. The optimal expression of TTSS genes can be obtained when the $P$. syringae bacteria are grown at 20 to $30^{\circ} \mathrm{C}$ (van Dijk et al. 1999). These environmental conditions are thought to simulate the physiological environment encountered by bacteria during infection. The factors influencing TTSS gene expression in the inducing medium differ somewhat between different pathogens, which may reflect the differences between the apoplastic conditions of different host species. For example, the nature of carbon source plays a critical role for TTSS gene activation, and fructose and sucrose are the best inducers of the $P$. syringae TTSS genes among the carbon sources tested (Huynh et al. 1989). Minimal medium supplemented with mannitol induced the $a v r B$ gene in $P$. syringae pv. glycinea almost as well as did the medium supplemented with fructose (Huynh et al. 1989); however, mannitol is unable to induce TTSS genes in $P$. syringae pv. phaseolicola strain NPS3121 (Y. Xiao and X. Tang, unpublished results). Differ- 
ential sugar effects also are established for $R$. solanacearum (Arlat et al. 1992). It is possible that in planta induction of TTSS genes requires both plant-specific signals and suitable physiological and chemical conditions in the plant apoplast.

In a recent study attempting to identify host signals involved in TTSS gene regulation, an Arabidopsis attl loss-of-function mutant was isolated that supports significantly higher induction of TTSS genes than did the wild-type plant (Xiao et al. 2004). This observation suggests the existence of plant-associated signals that negatively regulate TTSS genes. ATT1 encodes a cytochrome $P 450$ monooxygenase catalyzing fatty acid hydroxylation. In plants, hydroxylated fatty acids form extracellular polyesters that are major constituents of cutin, which envelopes the aerial part of the plant. The cutin content in attl mutant is reduced to $30 \%$ of the wild-type level, and the composition of cutin monomers also is largely altered in the att 1 mutant compared with the wild-type plant, indicating that ATT1 plays an important role in biosynthesis of cutin monomers. Certain commercially available fatty acids, such as 9,10epoxy stearic acid, and plant cutin extracts can specifically suppress the induction of TTSS genes (Xiao et al. 2004). Taken together, certain cutin monomer species may act as negative signals to regulate TTSS genes in planta. The negative regulation of TTSS genes by cutin-related signals may be important to epiphytic fitness of $P$. syringae bacteria that repress TTSS genes during epiphytic growth on the leaf surface (Xiao et al. 2004). How the cutin-related negative signal is perceived by $P$. syringae remains to be elucidated.

\section{The coregulation \\ of TTSS and other virulence-related genes.}

In addition to TTSS genes, in vivo expression technology assays in $P$. syringae, $R$. solanacearum, and Erwinia spp. have identified a large number of non-TTSS genes that also are induced in the plant (Boch et al. 2002; Brown and Allen 2004; Yang et al. 2004), indicating coregulation of TTSS genes with other biological processes during the bacterial interaction with plants. The regulatory mechanisms for many of the non-TTSS genes remain unclear. However, a number of the non-TTSS genes are induced by the $h r p$ regulators such as $h r p L, h r p B$, $h r p G$, and $h r p X$. Co-induction of these genes with TTSS genes likely enables the bacteria to cope with various stress factors encountered during the interaction with the plant and exploit the host nutrients to promote growth.

It has been shown in $P$. syringae pv. tomato DC3000 strain that the $i a a L, c f a l$, and $c f a 6$ genes are induced by $h r p L$ (Chang et al. 2005; Fouts et al. 2002; Lan et al. 2006). iaaL encodes indoleacetate-lysine ligase capable of producing IAA conjugates, an inactive form of the phytohormone auxin. iaaL has an "hrp box" motif in its promoter. DC3000 is capable of producing auxin (Glickmann et al. 1998) that may interfere with plant physiology. However, why the bacterium produces IaaL to inactivate auxin is not immediately understood. Genes $c f a l$ and $c f a 6$ are involved in the biosynthesis of the phytotoxin coronatine, an important virulence factor in several $P$. syringae strains (Mittal and Davis 1995). Genes cfal and cfa6 do not have the hrp box promoter and likely are induced by $h r p L$ indirectly via $\operatorname{cor} R$, the regulator of coronatine biosynthesis genes (Bender et al. 1999), that has a putative hrp box in its promoter (Fouts et al. 2002). In addition to these non-TTSS genes, our microarray analysis has identified several other DC3000 genes that apparently do not encode the type III effectors (Lan et al. 2006). Among these genes, PSPTOB0005 encodes a protein of the phosphoesterase family that is secreted from bacterial cells by the twin-arginine translocation pathway (Bronstein et al. 2005). PSPTO0873, PSPTO0874, and PSPTO0875 are likely to be organized in an operon and encode enzymes catalyzing the synthesis of certain secondary metabolites. PSPTO0834, PSPTO0835, and PSPTO0836 probably belong to another transcription unit encoding putative metabolic functions. PSPTO2691 encodes a membrane protein of the TerC family that is implicated in resistance to the toxic tellurium ions. A few of these genes also were shown to be HrpL-induced by Chang and associates (2005) using the HrpL-induced promoter assay. The identification of these genes indicated that the TTSS is coordinately activated with other protective or invasive mechanisms.

The coregulation of TTSS genes with other virulencerelated genes also was reported in $R$. solanacearum and Xanthomonas spp. In $R$. solanacearum, microarray analysis of $h r p B$-regulated genes has identified TTSS genes as well as genes with metabolic function, signal transduction and regulation, and acquisition and transport of exogenous compounds (Occhialini et al. 2005). Two hemagglutinin-like protein genes and two transposase genes also were shown to be $h r p B$ induced by microarray (Occhialini et al. 2005). A few of the $h r p B$ upregulated non-TTSS genes identified by microarray also were identified by the $h r p B$-dependent promoter trap assays (Mukaihara et al. 2004). A significant number of the $h r p B$ activated non-TTSS genes have the hrpII-box in their promoters. Similarly, a number of $h r p G / h r p X$-induced non-TTSS genes were identified by cDNA differential display in $X$. campestris pv. vesicatoria (Noel et al. 2001). It was reported recently that a gene encoding a protein secreted by the general secretion pathway in X. oryzae pv. oryzae has a "PIP box" promoter and is $h r p X$-activated (Furutani et al. 2004).

\section{Perspectives.}

The studies of bacterial TTSS gene regulation in the previous years enabled the construction of signal transduction pathways immediately upstream of the hrp/effector genes. Although additional regulatory genes have been identified regulating TTSS genes in various plant bacteria, the connection of these regulatory components with the downstream pathways remains obscure for most of these genes. The key puzzles for TTSS gene regulation are the identity and nature of the host and environmental signals regulating TTSS gene expression, the bacterial sensory proteins perceiving the signals, and the links between signal sensors and TTSS gene expression. The possible crosstalk between TTSS gene expression and other biochemical processes in bacteria also remains to be exploited.

\section{ACKNOWLEDGMENTS}

We would like to thank F. White for critical reading of the manuscript. This work was supported by the United States Department of Agriculture National Research Initiative Cooperative State Research Education and Extension Service grant number 2005-35319-15299, and is contribution number 06-288-J from the Kansas State University Agricultural Research Experimental Station.

\section{LITERATURE CITED}

Aldon, D., Brito, B., Boucher, C., and Genin, S. 2000. A bacterial sensor of plant cell contact controls the transcriptional induction of Ralstonia solanacearum pathogenicity genes. EMBO (Eur. Mol. Biol. Organ.) J. 19:2304-2314.

Alegria, M. C., Docena, C., Khater, L., Ramos, C. H., da Silva, A. C., and Farah, C. S. 2004. New protein-protein interactions identified for the regulatory and structural components and substrates of the type III Secretion system of the phytopathogen Xanthomonas axonopodis pathovar citri. J. Bacteriol. 186:6186-6197.

Alfano, J. R., Charkowski, A. O., Deng, W. L., Badel, J. L., PetnickiOcwieja, T., van Dijk, K., and Collmer, A. 2000. The Pseudomonas syringae Hrp pathogenicity island has a tripartite mosaic structure composed of a cluster of type III secretion genes bounded by exchangeable effector and conserved effector loci that contribute to parasitic fitness 
and pathogenicity in plants. Proc. Natl. Acad. Sci. U.S.A. 97:48564861 .

Alfano, J. R., and Collmer, A. 1997. The type III (Hrp) secretion pathway of plant pathogenic bacteria: Trafficking harpins, Avr proteins, and death. J. Bacteriol. 179:5655-5662.

Arlat, M., Gough, C. L., Zischek, C., Barberis, P. A., Trigalet, A., and Boucher, C. A. 1992. Transcriptional organization and expression of the large hrp gene cluster of Pseudomonas solanacearum. Mol. PlantMicrobe Interact. 5:187-193.

Arnold, D. L., Pitman, A., and Jackson, R. W. 2003. Pathogenicity and other genomic islands in plant pathogenic bacteria. Mol. Plant Pathol. 4:407-420.

Bender, C., Rangaswamy, V., and Loper, J. 1999. Polyketide production by plant-associated Pseudomonas. Annu. Rev. Phytopathol. 37:175-196.

Boch, J., Joardar, V., Gao, L., Robertson, T. L., Lim, M., and Kunkel, B. N. 2002. Identification of Pseudomonas syringae pv. tomato genes induced during infection of Arabidopsis thaliana. Mol. Microbiol. 44:7388.

Brencic, A., and Winans, S. C. 2005. Detection of and response to signals involved in host-microbe interactions by plant-associated bacteria. Microbiol. Mol. Biol. Rev. 69:155-194.

Bretz, J., Losada, L., Lisboa, K., and Hutcheson, S.W. 2002. Lon protease functions as a negative regulator of type III protein secretion in Pseudomonas syringae. Mol. Microbiol. 45:397-409.

Brito, B., Marenda, M., Barberis, P., Boucher, C., and Genin, S. 1999. prhJ and $h r p G$, two new components of the plant signal-dependent regulatory cascade controlled by PrhA in Ralstonia solanacearum. Mol. Microbiol. 31:237-251.

Brito, B., Aldon, D., Barberis, P., Boucher, C., and Genin, S. 2002. A signal transfer system through three compartments transduces the plant cell contact-dependent signal controlling Ralstonia solanacearum hrp genes. Mol. Plant-Microbe Interact. 15:109-119.

Bronstein, P. A., Marrichi, M., Cartinhour, S., Schneider, D. J., and DeLisa, M. P. 2005. Identification of a twin-arginine translocation system in Pseudomonas syringae pv. tomato DC3000 and its contribution to pathogenicity and fitness. J. Bacteriol. 187:8450-8461.

Brown, D. G, and Allen, C. 2004. Ralstonia solanacearum genes induced during growth in tomato: An inside view of bacterial wilt. Mol. Microbiol. 53:1641-1660

Buell, C. R., Joardar, V., Lindeberg, M., Selengut, J., Paulsen, I. T., Gwinn, M. L., Dodson, R. J., Deboy, R. T., Durkin, A. S., Kolonay, J. F., Madupu, R., Daugherty, S., Brinkac, L., Beanan, M. J., Haft, D. H., Nelson, W. C., Davidsen, T., Zafar, N., Zhou, L., Liu, J., Yuan, Q., Khouri, H., Fedorova, N., Tran, B., Russell, D., Berry, K., Utterback, T., Van Aken, S. E., Feldblyum, T. V., D’Ascenzo, M., Deng, W. L., Ramos, A. R., Alfano, J. R., Cartinhour, S., Chatterjee, A. K., Delaney, T. P., Lazarowitz, S. G., Martin, G. B., Schneider, D. J., Tang, X., Bender, C. L., White, O., Fraser, C. M., and Collmer, A. 2003. The complete genome sequence of the Arabidopsis and tomato pathogen Pseudomonas syringae pv. tomato DC3000. Proc. Natl. Acad. Sci. U.S.A. 100:10181-10186.

Buttner, D., and Bonas, U. 2002.Getting across-Bacterial type III effector proteins on their way to the plant cell. EMBO (Eur. Mol. Biol. Organ.) J. 21:5313-5322.

Chang, J. H., Urbach, J. M., Law, T. F., Arnold, L. W., Hu, A., Gombar, S., Grant, S. R., Ausubel, F. M., and Dangl, J. L. 2005. A high-throughput, near-saturating screen for type III effector genes from Pseudomonas syringae. Proc. Natl. Acad. Sci. U.S.A. 102:2549-2554.

Chatterjee, A., Cui, Y., and Chatterjee, A. K. 2002. Regulation of Erwinia carotovora hrpL(Ecc) (sigma-L(Ecc)), which encodes an extracytoplasmic function subfamily of sigma factor required for expression of the HRP regulon. Mol. Plant-Microbe Interact. 15:971-980.

Chatterjee, A., Cui, Y., Liu, Y., Dumenyo, C. K., and Chatterjee, A. K. 1995. Inactivation of rsmA leads to overproduction of extracellular pectinases, cellulases, and proteases in Erwinia carotovora subsp. carotovora in the absence of the starvation/cell density-sensing signal, $\mathrm{N}$-(3oxohexanoyl)-L-homoserine lactone. Appl. Environ. Microbiol. 61:1959-1967.

Chatterjee, A., Cui, Y., Yang, H., Collmer, A., Alfano, J. R., and Chatterjee, A. K. 2003. GacA, the response regulator of a two-component system, acts as a master regulator in Pseudomonas syringae pv. tomato DC3000 by controlling regulatory RNA, transcriptional activators, and alternate sigma factors. Mol. Plant-Microbe Interact. 16:1106-1117.

Cunnac, S., Boucher, C., and Genin, S. 2004a. Characterization of the cisacting regulatory element controlling HrpB-mediated activation of the type III secretion system and effector genes in Ralstonia solanacearum. J. Bacteriol. 186:2309-2318.

Cunnac, S., Occhialini, A., Barberis, P., Boucher, C., and Genin, S. 2004b. Inventory and functional analysis of the large Hrp regulon in Ralstonia solanacearum: Identification of novel effector proteins translocated to plant host cells through the type III secretion system. Mol. Microbiol. 53:115-128

da Silva, A. C., Ferro, J. A., Reinach, F. C., Farah, C. S., Furlan, L. R., Quaggio, R. B., Monteiro-Vitorello, C. B., Van Sluys, M. A., Almeida, N. F., Alves, L. M., do Amaral, A. M., Bertolini, M. C., Camargo, L. E., Camarotte, G., Cannavan, F., Cardozo, J., Chambergo, F., Ciapina, L. P., Cicarelli, R. M., Coutinho, L. L., Cursino-Santos, J. R., El-Dorry, H., Faria, J. B., Ferreira, A. J., Ferreira, R. C., Ferro, M. I., Formighieri, E. F., Franco, M. C., Greggio, C. C., Gruber, A., Katsuyama, A. M., Kishi, L. T., Leite, R. P., Lemos, E. G., Lemos, M. V., Locali, E. C., Machado, M. A., Madeira, A. M., Martinez-Rossi, N. M., Martins, E. C., Meidanis, J., Menck, C. F., Miyaki, C. Y., Moon, D. H., Moreira, L. M., Novo, M. T., Okura, V. K., Oliveira, M. C., Oliveira, V. R., Pereira, H. A., Rossi, A., Sena, J. A., Silva, C., de Souza, R. F., Spinola, L. A., Takita, M. A., Tamura, R. E., Teixeira, E. C., Tezza, R. I., Trindade dos Santos, M., Truffi, D., Tsai, S. M., White, F. F., Setubal, J. C., and Kitajima, J. P. 2002. Comparison of the genomes of two Xanthomonas pathogens with differing host specificities. Nature 417:459-463.

Dasgupta, N., Lykken, G. L., Wolfgang, M. C., and Yahr, T. L. 2004. A novel anti-anti-activator mechanism regulates expression of the Pseudomonas aeruginosa type III secretion system. Mol. Microbiol. 53:297-308.

Feil, H., Feil, W. S., Chain, P., Larimer, F., Dibartolo, G., Copeland, A., Lykidis, A., Trong, S., Nolan, M., Goltsman, E., Thiel, J., Malfatti, S., Loper, J. E., Lapidus, A., Detter, J. C., Land, M., Richardson, P. M., Kyrpides, N. C., Ivanova, N., and Lindow, S. E. 2005. Comparison of the complete genome sequences of Pseudomonas syringae pv. syringae B728a and pv. tomato DC3000. Proc. Natl. Acad. Sci. U.S.A. 102:11064-11069.

Fouts, D. E., Abramovitch, R. B., Alfano, J. R., Baldo, A. M., Buell, C. R., Cartinhour, S., Chatterjee, A. K., D’Ascenzo, M., Gwinn, M. L., Lazarowitz, S. G., Lin, N. C., Martin, G. B., Rehm, A. H., Schneider, D. J., van Dijk, K., Tang, X., and Collmer A., 2002. Genomewide identification of Pseudomonas syringae pv. tomato DC3000 promoters controlled by the HrpL alternative sigma factor. Proc. Natl. Acad. Sci. U.S.A. 99:2275-2280.

Francis, M. S., Wolf-Watz, H., and Forsberg, A. 2002. Regulation of type III secretion systems. Curr. Opin. Microbiol. 5:166-172.

Frederick, R. D., Ahmad, M., Majerczak, D. R., Arroyo-Rodriguez, A. S., Manulis, S., and Coplin, D. L. 2001. Genetic organization of the Pantoea stewartii subsp. stewartii hrp gene cluster and sequence analysis of the $h r p A, h r p C, h r p N$, and wtsE operons. Mol. Plant-Microbe Interact. 14:1213-1222.

Furutani, A., Tsuge, S., Ohnishi, K., Hikichi, Y., Oku, T., Tsuno, K., Inoue, Y., Ochiai, H., Kaku, H., and Kubo, Y. 2004. Evidence for HrpXodependent expression of type II secretory proteins in Xanthomonas oryzae pv. oryzae. J. Bacteriol. 186:1374-1380.

Galan, J. E., and Collmer, A. 1999. Type III secretion machines: Bacterial devices for protein delivery into host cells. Science 284:1322-1328.

Genin, S., Brito, B., Denny, T. P., and Boucher, C. 2005. Control of the Ralstonia solanacearum Type III secretion system (Hrp) genes by the global virulence regulator PhcA. FEBS (Fed. Eur. Biochem. Soc.) Lett. 579:2077-2081.

Genin, S., Gough, C. L., Zischek, C., and Boucher, C. A. 1992. Evidence that the $h r p B$ gene encodes a positive regulator of pathogenicity genes from Pseudomonas solanacearum. Mol. Microbiol. 6:3065-3076.

Glickmann, E., Gardan, L., Jacquet, S., Hussain, S., Elasri, M., Petit, A., and Dessaux, Y. 1998. Auxin production is a common feature of most pathovars of Pseudomonas syringae. Mol. Plant-Microbe Interact. $11: 156-162$.

Grimm, C., Aufsatz, W., and Panopoulos, N. J. 1995. The hrpRS locus of Pseudomonas syringae pv. phaseolicola constitutes a complex regulatory unit. Mol. Microbiol. 15:155-165.

Heeb, S., and Haas, D. 2001. Regulatory roles of the GacS/GacA twocomponent system in plant-associated and other gram-negative bacteria Mol. Plant-Microbe Interact. 14:1351-1363.

Hendrickson, E. L., Guevera, P., and Ausubel, F. M. 2000. The alternative sigma factor RpoN is required for hrp activity in Pseudomonas syringae pv. maculicola and acts at the level of hrpL transcription. J. Bacteriol. 182:3508-3516.

Hovey, A. K., and Frank, D. W. 1995. Analysis of the DNA-binding and transcriptional activation properties of ExsA, a transcriptional activator of Pseudomonas aeruginosa exoenzyme $\mathrm{S}$ regulon. J. Bacteriol. 177:4427-4436.

Hutcheson, S. W., Bretz, J., Sussan, T., Jin, S., and Pak, K. 2001. Enhancer-binding proteins HrpR and HrpS interact to regulate hrp-encoded type III protein secretion in Pseudomonas syringae strains. J. Bacteriol. 183:5589-5598.

Huynh, T. V., Dahlbeck, D., and Staskawicz, B. J. 1989. Bacterial blight of soybean: Regulation of a pathogen gene determining host cultivar specificity. Science 245:1374-1377. 
Jin, Q., and He, S.Y. 2001. Role of the Hrp pilus in type III protein secretion in Pseudomonas syringae. Science 294:2556-2558.

Joardar, V., Lindeberg, M., Jackson, R., Selengut, J., Dodson, R., Brinkac, L. M., Daugherty, S. C., Deboy, R., Durkin, A. S., Giglio, M. G., Madupu, R., Nelson, W. C., Rosovitz, M. J., Sullivan, S., Crabtree, J., Creasy, T., Davidsen, T., Haft, D. H., Zafar, N., Zhou, L., Halpin, R., Holley, T., Khouri, H., Feldblyum, T., White, O., Fraser, C. M., Chatterjee, A. K., Cartinhour, S., Schneider, D. J., Mansfield, J., Collmer, A., and Buell, C. R. 2005. Whole-genome sequence analysis of Pseudomonas syringae pv. phaseolicola 1448A reveals divergence among pathovars in genes involved in virulence and transposition. J. Bacteriol. 187:6488-6498.

Kamdar, H. V., Kamoun, S., and Kado, C. I. 1993. Restoration of pathogenicity of avirulent Xanthomonas oryzae pv. oryzae and X. campestris pathovars by reciprocal complementation with the $h r p X o$ and $h r p X c$ genes and identification of HrpX function by sequence analyses. J. Bacteriol. 175:2017-2025.

Kubori, T., Matsushima, Y., Nakamura, D., Uralil, J., Lara-Tejero, M., Sukhan, A., Galan, J. E., and Aizawa, S. I. 1998. Supramolecular structure of the Salmonella typhimurium type III protein secretion system. Science 280:602-605.

Lan, L., Deng, X., Zhou, J., and Tang, X. 2006. Genome-wide gene expression analysis of Pseudomonas syringae pv. tomato DC3000 reveals overlapping and distinct pathways regulated by $h r p L$ and $h r p R S$. Mol. Plant-Microbe Interact. 19:976-987.

Li, C. M., Brown, I., Mansfield, J., Stevens, C., Boureau, T., Romantschuk, M., and Taira, S. 2002. The Hrp pilus of Pseudomonas syringae elongates from its tip and acts as a conduit for translocation of the effector protein HrpZ. EMBO (Eur. Mol. Biol. Organ.) J. 21:1909-1915.

Liu, Y., Cui, Y., Mukherjee, A., and Chatterjee, A. K. 1998. Characterization of a novel RNA regulator of Erwinia carotovora ssp. Carotovora that controls production of extracellular enzymes and secondary metabolites. Mol. Microbiol. 29:219-234.

Losada, L., Sussan, T., Pak, K., Zeyad, S., Rozenbaum, I., and Hutcheson, S. W. 2004. Identification of a novel Pseudomonas syringae Psy61 effector with virulence and avirulence functions by a HrpL-dependent promoter-trap assay. Mol. Plant-Microbe Interact. 17:254-262.

Losada, L. C, and Hutcheson, S. W. 2005. Type III secretion chaperones of Pseudomonas syringae protect effectors from Lon-associated degradation. Mol. Microbiol. 55:941-953.

Marenda, M., Brito, B., Callard, D., Genin, S., Barberis, P., Boucher, C., and Arlat, M. 1998. PrhA controls a novel regulatory pathway required for the specific induction of Ralstonia solanacearum hrp genes in the presence of plant cells. Mol. Microbiol. 27:437-453.

Marlovits, T. C., Kubori, T., Sukhan, A., Thomas, D. R., Galan, J. E., and Unger, V. M. 2004. Structural insights into the assembly of the type III secretion needle complex. Science 306:1040-1042.

McCaw, M. L., Lykken, G. L., Singh, P. K., and Yahr, T. L. 2002. ExsD is a negative regulator of the Pseudomonas aeruginosa type III secretion regulon. Mol. Microbiol. 46:1123-1133.

Merighi, M., Majerczak, D. R., Stover, E. H., and Coplin, D. L. 2003. The HrpX/HrpY two-component system activates hrpS expression, the first step in the regulatory cascade controlling the Hrp regulon in Pantoea stewartii subsp. stewartii. Mol. Plant-Microbe Interact. 16:238-248.

Mittal, S., and Davis, K. R. 1995. Role of the phytotoxin coronatine in the infection of Arabidopsis thaliana by Pseudomonas syringae pv. tomato. Mol. Plant-Microbe Interact. 8:165-171.

Mor, H., Manulis, S., Zuck, M., Nizan, R., Coplin, D. L., and Barash, I. 2001. Genetic organization of the $h r p$ gene cluster and $d s p A E / B F$ operon in Erwinia herbicola pv. gypsophilae. Mol. Plant-Microbe Interact. 14:431-436

Mukaihara, T., Tamura, N., Murata, Y., and Iwabuchi, M. 2004. Genetic screening of Hrp type III-related pathogenicity genes controlled by the HrpB transcriptional activator in Ralstonia solanacearum. Mol. Microbiol. 54:863-875.

Nissan, G., Manulis, S., Weinthal, D. M., Sessa, G., and Barash, I. 2005. Analysis of promoters recognized by $\mathrm{HrpL}$, an alternative sigma-factor protein from Pantoea agglomerans pv. gypsophilae. Mol. PlantMicrobe Interact. 18:634-643.

Nizan-Koren, R., Manulis, S., Mor, H., Iraki, N. M., and Barash, I. 2003. The regulatory cascade that activates the Hrp regulon in Erwinia herbicola pv. gypsophilae. Mol. Plant-Microbe Interact. 16:249-260.

Noel, L., Thieme, F., Nennstiel, D., and Bonas, U. 2001. cDNA-AFLP analysis unravels a genome-wide $h r p G$-regulon in the plant pathogen Xanthomonas campestris pv. vesicatoria. Mol. Microbiol. 41:12711281.

Occhialini, A., Cunnac, S., Reymond, N., Genin, S., and Boucher, C. 2005. Genome-wide analysis of gene expression in Ralstonia solanacearum reveals that the $h r p B$ gene acts as a regulatory switch controlling multiple virulence pathways. Mol. Plant-Microbe Interact. 18:938-949.
Pettersson, J., Nordfelth, R., Dubinina, E., Bergman, T., Gustafsson, M. Magnusson, K. E., and Wolf-Watz, H. 1996. Modulation of virulence factor expression by pathogen target cell contact. Science 273:12311233

Preston, G., Deng, W. L., Huang, H. C., and Collmer, A. 1998. Negative regulation of hrp genes in Pseudomonas syringae by HrpV. J. Bacteriol. 180:4532-4537.

Rahme, L. G., Mindrinos, M. N., and Panopoulos, N. J. 1992. Plant and environmental sensory signals control the expression of hrp genes in Pseudomonas syringae pv. phaseolicola. J. Bacteriol. 174:3499-3507.

Roine, E., Wei, W., Yuan, J., Nurmiaho-Lassila, E. L., Kalkkinen, N., Romantschuk, M., and He, S. Y. 1997. Hrp pilus: An hrp-dependent bacterial surface appendage produced by Pseudomonas syringae pv. tomato DC3000. Proc. Natl. Acad. Sci. U.S.A. 94:3459-3464.

Schell, M. A. 2000. Control of virulence and pathogenicity genes of Ralstonia solanacearum by elaborate sensory network. Annu. Rev. Phytopathol. 38:263-292.

Schulte, R., and Bonas, U. 1992. Expression of the Xanthomonas campestris pv. vesicatoria hrp gene cluster, which determines pathogenicity and hypersensitivity on pepper and tomato, is plant inducible. J. Bacteriol. 174:815-823.

Stainier, I., Iriarte, M., and Cornelis, G. R. 1997. YscM1 and YscM2, two Yersinia enterocolitica proteins causing downregulation of yop transcription. Mol. Microbiol. 26:833-843.

Thieme, F., Koebnik, R., Bekel, T., Berger, C., Boch, J., Buttner, D., Caldana, C., Gaigalat, L., Goesmann, A., Kay, S., Kirchner, O., Lanz, C., Linke, B., McHardy, A. C., Meyer, F., Mittenhuber, G., Nies, D. H., Niesbach-Klosgen, U., Patschkowski, T., Ruckert, C., Rupp, O., Schneiker, S., Schuster, S. C., Vorholter, F. J., Weber, E., Puhler, A., Bonas, U., Bartels, D., and Kaiser, O. 2005. Insights into genome plasticity and pathogenicity of the plant pathogenic bacterium Xanthomonas campestris pv. vesicatoria revealed by the complete genome sequence. J. Bacteriol. 187:7254-7266.

Thwaites, R., Spanu, P. D., Panopoulos, N. J., Stevens, C., and Mansfield, J. W., 2004. Transcriptional regulation of components of the type III secretion system and effectors in Pseudomonas syringae pv. phaseolicola. Mol. Plant-Microbe Interact. 17:1250-1258.

Tsuge, S., Terashima, S., Furutani, A., Ochiai, H., Oku, T., Tsuno, K. Kaku, H., and Kubo, Y. 2005. Effects on promoter activity of base substitutions in the cis-acting regulatory element of HrpXo regulons in Xanthomonas oryzae pv. oryzae. J. Bacteriol. 187:2308-2314.

van Dijk, K., Fouts, D. E., Rehm, A. H., Hill, A. R., Collmer, A., and Alfano, J. R. 1999. The Avr (effector) proteins HrmA (HopPsyA) and AvrPto are secreted in culture from Pseudomonas syringae pathovars via the Hrp (type III) protein secretion system in a temperature- and pH-sensitive manner. J. Bacteriol. 181:4790-4797.

Van Gijsegem, F., Vasse, J., Camus, J. C., Marenda, M., and Boucher, C. 2000. Ralstonia solanacearum produces hrp-dependent pili that are required for PopA secretion but not for attachment of bacteria to plant cells. Mol. Microbiol. 36:249-260.

Weber, E., Ojanen-Reuhs, T., Huguet, E., Hause, G., Romantschuk, M., Korhonen, T. K., Bonas, U., and Koebnik, R. 2005. The type III-dependent Hrp pilus is required for productive interaction of Xanthomonas campestris pv. vesicatoria with pepper host plants. J. Bacteriol. 187:2458-2468.

Wei, C. F., Deng, W. L., and Huang, H. C., 2005. A chaperone-like HrpG protein acts as a suppressor of $\mathrm{HrpV}$ in regulation of the Pseudomonas syringae pv. syringae type III secretion system. Mol. Microbiol. 57:520-536.

Wei, W., Plovanich-Jones, A., Deng, W. L., Jin, Q. L., Collmer, A., Huang, H. C., and He, S. Y., 2000a. The gene coding for the Hrp pilus structural protein is required for type III secretion of Hrp and Avr proteins in Pseudomonas syringae pv. tomato. Proc. Natl. Acad. Sci. U.S.A. 97:2247-2252.

Wei, Z., Kim, J. F., and Beer, S. V. 2000b. Regulation of $h r p$ genes and type III protein secretion in Erwinia amylovora by HrpX/HrpY, a novel two-component system, and HrpS. Mol. Plant-Microbe Interact. 13:1251-1262.

Wei, Z. M., and Beer, S. V. 1995. hrpL activates Erwinia amylovora hrp gene transcription and is a member of the ECF subfamily of sigma factors. J. Bacteriol. 177:6201-6210.

Wei, Z. M., Sneath, B. J., and Beer, S. V. 1992. Expression of Erwinia amylovora hrp genes in response to environmental stimuli. J. Bacteriol. 174:1875-1882.

Wengelnik, K., and Bonas, U. 1996. HrpXv, an AraC-type regulator, activates expression of five of the six loci in the $h r p$ cluster of Xanthomonas campestris pv. vesicatoria. J. Bacteriol. 178:3462-3469.

Wengelnik, K., Rossier, O., and Bonas, U. 1999. Mutations in the regulatory gene hrpG of Xanthomonas campestris pv. vesicatoria result in constitutive expression of all $h r p$ genes. J. Bacteriol. 181:6828-6831. 
Wengelnik, K., Van den Ackerveken, G., and Bonas, U. 1996. HrpG, a key hrp regulatory protein of Xanthomonas campestris pv. vesicatoria is homologous to two-component response regulators. Mol. Plant-Microbe Interact. 9:704-712.

Xiao, F., Goodwin, S. M., Xiao, Y., Sun, Z., Baker, D., Tang, X., Jenks, M. A., and Zhou, J. M., 2004. Arabidopsis CYP86A2 represses Pseudomonas syringae type III genes and is required for cuticle development. EMBO (Eur. Mol. Biol. Organ.) J. 23:2903-2913.

Xiao, Y., Heu, S., Yi, J., Lu, Y., and Hutcheson, S. W. 1994. Identification of a putative alternate sigma factor and characterization of a multicomponent regulatory cascade controlling the expression of Pseudomonas syringae pv. syringae Pss61 hrp and hrmA genes. J. Bacteriol. $176: 1025-1036$
Xiao, Y., Lu, Y., Heu, S., and Hutcheson, S. W. 1992. Organization and environmental regulation of the Pseudomonas syringae pv. syringae 61 hrp cluster. J. Bacteriol. 174:1734-1741.

Yang, S., Perna, N. T., Cooksey, D. A., Okinaka, Y., Lindow, S. E., Ibekwe, A. M., Keen, N. T., and Yang, C. H. 2004. Genome-wide identification of plant-upregulated genes of Erwinia chrysanthemi 3937 using a GFP-based IVET leaf array. Mol. Plant-Microbe Interact. 17:999-1008.

Zwiesler-Vollick, J., Plovanich-Jones, A. E., Nomura, K., Bandyopadhyay, S., Joardar, V., Kunkel, B. N., and He, S. Y. 2002. Identification of novel hrp-regulated genes through functional genomic analysis of the Pseudomonas syringae pv. tomato DC3000 genome. Mol. Microbiol. 45:12071218 . 